\title{
In vitro genotoxicity assessment of an oxidized dextrin-based hydrogel for biomedical applications
}

\author{
Isabel Pereira ${ }^{1}$ (1) | Sónia Fraga ${ }^{2,3}$ | Susana Silva ${ }^{2,3}$ | João Paulo Teixeira ${ }^{2,3}$ | Miguel Gama ${ }^{1}$
}

${ }^{1}$ CEB-Centre of Biological Engineering, University of Minho, Campus de Gualtar, 4710-057 Braga, Portugal

${ }^{2}$ Departamento de Saúde Ambiental, Instituto Nacional de Saúde Dr. Ricardo Jorge, 4000055 Porto, Portugal

${ }^{3}$ EPIUnit-Instituto de Saúde Pública, Universidade do Porto, 4050-600 Porto, Portugal

Correspondence

Isabel Pereira, Centre of Biological

Engineering, University of Minho, Campus de Gualtar, 4710-057 Braga, Portugal

Email: isabelsofia.isport@gmail.pt

Funding information

FEDER - Fundo Europeu de Desenvolvimento Regional, Grant/Award Numbers: NORTE-010145-FEDER-000004 and NORTE-01-0247FEDER-003262; Fundação para a Ciência e a Tecnologia, Grant/Award Numbers: PTDC/ CTM-BIO/2170/2014, SFRH/BD/ $90066 / 2012$

\begin{abstract}
Hydrogels are three-dimensional, crosslinked networks of hydrophilic polymers swollen with a large amount of water or biological fluids, without dissolving. Dextrin, a low-molecular-weight carbohydrate composed by glucose residues, has been used to develop an injectable hydrogel for biomedical applications. Dextrin was first oxidized to introduce aldehyde groups, which then reticulate with adipic acid dihydrazide, forming the dextrin-based hydrogel (HG). The HG and its components were tested for cyto- and genotoxicity according to the International Standard ISO 10993-3 on the biological evaluation of medical devices. To assess genotoxicity, a battery of in vitro genotoxicity tests employing both eukaryotic and prokaryotic models was performed: comet assay, cytokinesis-block micronucleus assay and Ames test. Our data revealed that the $\mathrm{HG}\left(\mathrm{IC}_{50}=2.8 \mathrm{mg} / \mathrm{mL}\right)$ and oxidized dextrin by itself $\left(\mathrm{IC}_{50}=1.2 \mathrm{mg} / \mathrm{mL}\right)$ caused a concentration-dependent decrease in cellular viability of human lymphoblastoid TK6 cells after 24 hours of exposure to the test agents. However, these concentrations are unlikely to be reached in vivo. In addition, no significant increase in the DNA and chromosomal damage of TK6 cells exposed to non-cytotoxic concentrations of the HG and its isolated components was detected. Furthermore, neither the HG nor its metabolites exerted a mutagenic effect in different of Salmonella typhimurium strains and in an Escherichia coli mix. Our data demonstrated the genocompatibility of the HG (up to $3.5 \mathrm{mg} / \mathrm{mL}$ ) for biomedical applications. To our best acknowledge, this is the first report with a detailed genotoxicity assessment of an aldehyde-modified polysaccharide/adipic acid dihydrazide hydrogel.
\end{abstract}

\section{KEYWORDS}

adipic acid dihydrazide (ADH), aldehyde-modified polysaccharide, Ames test, comet assay, cytokinesis-block micronucleus (CBMN) assay, dextrin, hydrogel, TK6 cells

\section{1 | INTRODUCTION}

Hydrogels are three-dimensional, crosslinked networks of hydrophilic polymers swollen with a large amount of water or biological fluids. They generally are biocompatible, biodegradable and mimic many of the properties of the native extracellular matrix, namely high-water content and viscoelastic mechanical properties, functional activity as provisional artificial support for cells and lack of mechanical strength. They display porosity and interconnectivity, enabling the transport of nutrients, gas diffusion and removal of metabolic wastes, and they can act as carriers of growth factors or cells and as drug delivery systems. Moreover, hydrogels can be injectable, enabling less invasive clinical procedures, and can conform to the shape of the surface to which they are applied. Therefore, hydrogels are used in clinical practice and experimental medicine in diverse applications, including tissue engineering and as drug delivery systems (Drury \& Mooney, 2003; Geckil, Xu, Zhang, Moon, \& Demirci, 2010; Hoare \& Kohane, 2008). 
Dextrins are low-molecular-weight carbohydrates produced by partial hydrolysis of glycogen or starch obtained under acidic and/or enzymatic conditions (Gonçalves, Moreira, Carvalho, Silva, \& Gama, 2016). They are composed by a linear ( $a 1 \rightarrow 4$ )-D-glucose residues backbone, branched with ( $a 1 \rightarrow 4,6$ )-linked-D-glucose residues. Some dextrins also present ( $a 1 \rightarrow 6$ )-D-glucose residues in a small percentage (Silva et al., 2014; Tomasik, Wiejak, \& Pałasiński, 1989).

Dextrin is a low cost, broadly available raw material, generally regarded as safe and widely used in many industrial applications, such as adhesives, textiles, cosmetics and foods (Gonçalves et al., 2016; Tomasik et al., 1989). Regarding biomedical applications, dextrin is still relatively unexplored, being clinically used as a peritoneal dialysis solution that can also perform as a drug delivery solution (Peers \& Gokal, 1998; Takatori et al., 2011; Treetharnmathurot et al., 2009), and as a wound dressing agent (DeBusk \& Alleman, 2006). Although there are limited numbers of current biomedical applications, dextrin displays a set of advantages that potentiates its use specifically in the biomaterials field. It is a biocompatible and non-immunogenic material, degradable in vivo by $\alpha$-amylases and its molecular weight ensures renal elimination avoiding tissue accumulation upon repeated administration (Hreczuk-Hirst, Chicco, German, \& Duncan, 2001; Moreira et al., 2010). During the last decade, due to its properties, which include the solubility in both water and dimethyl sulfoxide (DMSO), availability in medical grade, and availability of hydroxyl groups, dextrin has been explored for the design and fabrication of hydrogels suitable for controlled release applications and as tissue engineering scaffolds (Das \& Pal, 2015; Gonçalves et al., 2016).

Dextrin has been used by our research group to develop a novel fully resorbable and injectable hydrogel. Dextrin was first oxidized (ODEX) with sodium periodate to produce dialdehydes, which in turn then reticulate with adipic acid dihydrazide (ADH), forming the dextrin-based hydrogel (HG) (Figure 1) (Molinos, Carvalho, Silva, \& Gama, 2012). The cross-linked ODEX is an in situ gelling hydrogel, which displays a three-dimensional network with interconnective pores, and is able to incorporate nanogels, cells and biomolecules for biomedical applications (Molinos et al., 2012; Silva et al., 2014; Silva et al., 2016).

The development of biomaterials for medical applications includes extensive preclinical testing to demonstrate their safety and efficacy according to the regulatory agencies requirements. In this context, our group has already shown the in vivo biocompatibility of the HG after subcutaneous implantation in a rat model (Silva et al., 2016). In the same study, the HG was associated with granular ceramics and was able to stabilize the granules in the implant site, demonstrating its potential for the development of injectable bone substitutes (Silva et al., 2016).

The systemic biocompatibility testing of materials includes genotoxicity assessment-evaluation of the presence of a DNA reactive component that may result in mutagenicity and carcinogenicity. The International Standard ISO 10993 on the biological evaluation of medical devices stipulates that implant devices developed to be in contact with tissue/bone and blood for longer than 24 hours must undergo genotoxicity assessment (ISO 10993-1, 2009). A battery of in vitro genotoxicity tests employing prokaryotic and eukaryotic models shall be used to determine the potential to induce gene mutations, changes in chromosome structure and number, and other DNA or gene abnormalities caused by the medical devices, materials and/or their extracts (ISO 10993-3, 2014). Thus, in the present work, the genotoxic potential of the dextrin-based hydrogel (HG) and its isolated components (ODEX and ADH) was assessed by the Ames test, micronucleus (MN) and comet assays.

\section{2 | MATERIALS AND METHODS}

\section{1 | Chemicals}

All chemicals used were of the highest purity or analytical grade available. Dextrin used in this work was Tackidex B 167 (batch E 1445), generously assigned by Roquette (Lestrem, France). Sodium m-periodate (CAS no. 7790-28-5), diethylene glycol (CAS no. 11146-6) and ADH (CAS no. 1071-93-8), 3-(4,5-dimethylthiazol-2-yl)2,5-diphenyltetrazolium bromide (MTT; CAS no. 298-93-1), methyl methanesulfonate (MMS; CAS no. 66-27-3), DMSO (CAS no. 37-685), Triton X-100 (CAS no. 9002-93-1), low melting point agarose (CAS no. 39346-81-1) and cytochalasin B (cytoB; CAS no. 1493096-2) were purchased from Sigma-Aldrich (St. Louis, MO, USA). Absolute ethanol (CAS no. 64-17-5), sodium hydroxide ( $\mathrm{NaOH}$; CAS no. 1310-73-2), sodium chloride ( $\mathrm{NaCl}$; $\mathrm{CAS}$ no. 7647-14-5),
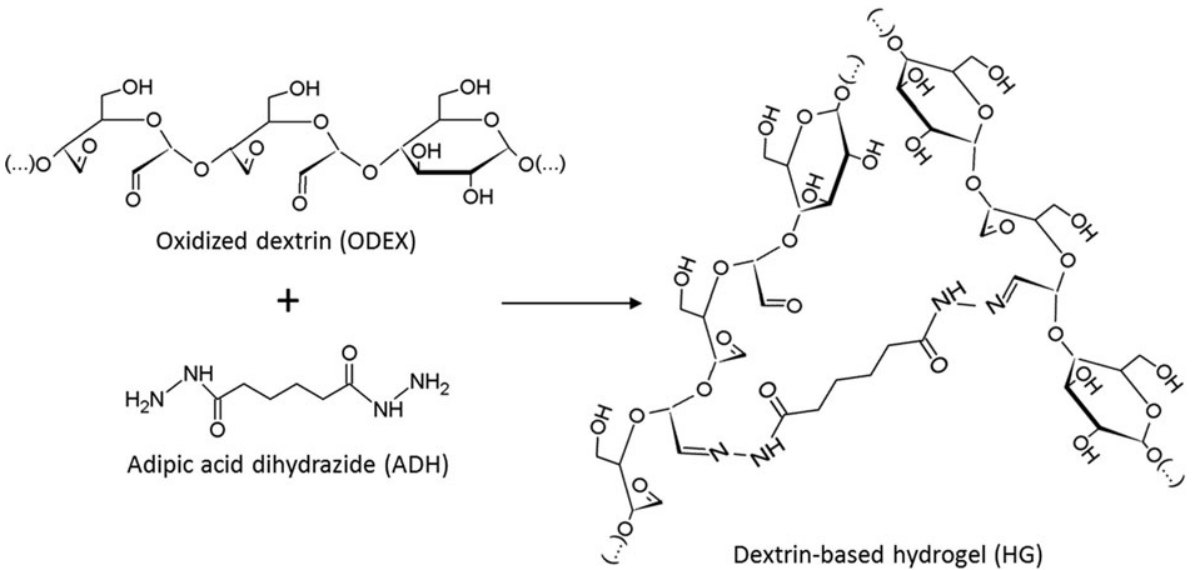

FIGURE 1 Chemical structures of oxidized dextrin, adipic acid dihydrazide and of the corresponding hydrogel formed after reticulation reaction between oxidized dextrin and adipic acid dihydrazide 
hydrochloric acid (CAS no. 7647-01-0), acetic acid (CAS no. 64-19-7), Tris base (CAS no. 77-86-1) and Giemsa's azur eosin methylene blue (CAS no. 51811-82-6) were obtained from Merck (Darmstadt, Germany). Mitomycin C (MMC; CAS no. 50-07-7) and Molecular Probes ${ }^{\circledR}$ SYBR $^{\circledR}$ Gold was purchased from Thermo Fisher Scientific (Waltham, MA, USA), while ethylenediaminetetraacetic acid disodium salt ( $\mathrm{Na}_{2} \mathrm{EDTA}$; CAS no. 6381-92-6) was obtained from Prolab (Quebec, Canada). Phosphate-buffered saline (PBS; CAS no. 1004921-5) and normal melting point agarose were supplied by Lonza (Basel, Switzerland), while methanol (CAS no. 67-56-1) was purchased from VWR (Radnor, PA, USA).

\section{2 | Material preparation}

\subsection{1 | Dextrin oxidation}

Dextrin oxidation was performed as described by Pereira et al. (2018). Briefly, aqueous solutions of dextrin $(2 \% \mathrm{w} / \mathrm{v})$ were oxidized with sodium $m$-periodate, to yield the theoretical degree of oxidation of $40 \%$, at room temperature, with stirring, and in the dark. After 20 hours, the oxidation reaction was stopped by dropwise addition of an equimolar amount of diethylene glycol to reduce any unreacted periodate. Sodium $m$-periodate and diethylene glycol were removed by ultrafiltration, using a membrane with a molecular weight cut-off 1000 Da (Merck Millipore, Billerica, MA, USA), and then lyophilized.

\subsection{2 | Preparation of the dextrin-based hydrogel}

ODEX was dissolved in PBS solution $(30 \% \mathrm{w} / \mathrm{v})$ and the solution was sterilized by gamma irradiation (IONISOS, Dagneux, France), using a ${ }^{60} \mathrm{Co}$ source, at $20 \mathrm{kGy}(2 \mathrm{kGy} / \mathrm{h})$, at room temperature. $\mathrm{ADH}$ was also dissolved in PBS solution ( $3.76 \% \mathrm{w} / \mathrm{v}$ ) and sterilized by filtration, using a $0.22 \mu \mathrm{m}$ pore filter membrane (Pall Corporation, Ann Arbor, MI, USA). For the crosslinking reaction, ODEX and ADH solutions were mixed in a 7:3 volume ratio, respectively.

\section{3 | Cell culture}

The human lymphoblastoid TK6 cell line $\left(\right.$ ATCC $^{\circledR}$ CRL8015 ${ }^{\text {TM }}$ ) was used for the cyto- and genotoxicity testing. The cells were maintained in RPMI-1640 medium (Thermo Fisher Scientific) with $2 \mathrm{mM}$ glutamine supplemented with $10 \%$ heat-inactivated fetal bovine serum (Thermo Fisher Scientific), 100 units $/ \mathrm{mL}$ of penicillin, $100 \mu \mathrm{g} / \mathrm{mL}$ of streptomycin and $0.25 \mu \mathrm{g} / \mathrm{mL}$ of amphotericin (Thermo Fisher Scientific). Cells were maintained in a humidified atmosphere with $5 \% \mathrm{CO}_{2}$ at $37^{\circ} \mathrm{C}$.

\section{4 | Cell exposure conditions}

For cyto- and genotoxicity testing, the HG was tested by an indirect method, as the $\mathrm{HG}$ is not pipettable, it was diluted $\left(\mathrm{HG}_{\mathrm{dil}}\right)$ in culture medium and different concentrations were prepared and tested (Table 1). The HG constituents (ODEX and ADH), which are two of its degradation products, were also tested separately, using the same concentrations used for the assessment of the $\mathrm{HG}_{\text {dil }}$ tested (Table 1). Thus, for the MTT reduction and cytokinesis-block MN (CBMN)
TABLE 1 Concentrations of the $\mathrm{HG}_{\text {dil }}$, ODEX and $\mathrm{ADH}$ used in the cyto- and genotoxicity testing

\begin{tabular}{llll} 
& $\mathrm{HG}_{\text {dil }}(\mathrm{mg} / \mathrm{mL})$ & ODEX $(\mathrm{mg} / \mathrm{mL})$ & ADH $(\mathrm{mg} / \mathrm{mL})$ \\
$\mathrm{NC}$ & 0.000 & 0.000 & 0.000 \\
$\mathrm{C} 1$ & 0.124 & 0.118 & 0.006 \\
$\mathrm{C} 2$ & 0.248 & 0.235 & 0.013 \\
C3 & 0.491 & 0.466 & 0.034 \\
C4 & 0.965 & 0.916 & 0.049 \\
C5 & 1.865 & 1.770 & 0.095 \\
C6 & 3.494 & 3.316 & 0.178 \\
\hline
\end{tabular}

$\mathrm{ADH}$, adipic acid dihydrazide; $\mathrm{HG}_{\text {dil, }}$ diluted dextrin-based hydrogel; ODEX, oxidized dextrin.

assays, six concentrations of the $\mathrm{HG}_{\mathrm{dil}}$ (C1-C6) were tested in parallel with its individual components (ODEX and ADH) (Table 1). For the comet assay, three non-cytotoxic concentrations were tested (C1-C3). In the Ames test, only six different concentrations of $\mathrm{HG}_{\text {dil }}$ were tested (C1-C6). For all the experiments, a negative control (NC) and an appropriate positive control (PC) were used.

\subsection{Assessment of the cellular viability}

The cytotoxicity of the HG, ODEX and ADH was evaluated based on their effects on cell viability assessed by the MTT reduction assay following 24 hours of exposure, as recommended in ISO 10993-5 (2009). To carry out the experiment, $1.7 \times 10^{5}$ cells $/ \mathrm{mL}$ were seeded in 96-well round bottom plates. After 24 hours, cells were incubated with different concentrations of the $\mathrm{HG}_{\text {dil }}$, ODEX and $\mathrm{ADH}$, culture medium (NC) or with DMSO (PC). At the end of the exposure period (24 hours), the test agents were removed by centrifugation (130 g, 2 minutes) and $100 \mu \mathrm{L}$ of MTT solution ( $1 \mathrm{mg} / \mathrm{mL}$ in serum-free culture medium) were added to each well and incubated for 3 hours at $37^{\circ} \mathrm{C}$ in the dark. For MTT removal, plates were centrifuged ( $300 \mathrm{~g}, 10$ minutes), and the produced formazan was solubilized with $200 \mu \mathrm{L}$ DMSO. Thereafter, $150 \mu \mathrm{L}$ of the supernatant were transferred to a 96-well flat bottom plate and the absorbance was measured at 570 and $690 \mathrm{~nm}$ (reference wavelength), using a Cambrex ELx808 microplate reader (BioTek, Winooski, VT, USA). Two independent experiments were performed, each in triplicate.

\subsection{Assessment of the DNA damage}

The comet assay, also known as single-cell gel electrophoresis assay, was performed to evaluate the potential DNA damage induced by the HG and its components. For that purpose, TK6 cells were seeded on to 24 -well plates at a density of $1.7 \times 10^{5}$ cells $/ \mathrm{mL}$. After 24 hours, cells were treated with non-toxic concentrations of $\mathrm{HG}_{\text {dil }}$, ODEX and $\mathrm{ADH}$ (C1-C3), selected based on the cellular viability data. Cells incubated with culture medium and the DNA alkylating agent MMS ( $40 \mathrm{\mu g} / \mathrm{mL}$; 1 hour) served as NC and PC, respectively. At the end of the exposure period ( 24 hours), incubation media were removed and cells washed with PBS $\mathrm{pH}$ 7.4. The comet assay was performed in alkaline conditions $(\mathrm{pH}>13)$ as previously described by Mesquita et al. (2017), with minor modifications. All the steps described were 
conducted under a reduced light level to prevent additional DNA damage. Briefly, aliquots of $1 \times 10^{5}$ cells in PBS were centrifuged at $400 \mathrm{~g}$ for 3 minutes. The cell pellets were resuspended in $100 \mu \mathrm{L} 1 \%$ low melting point agarose and $5 \mu \mathrm{L}$ of each cell suspension layered on to dry microscope slides (VWR, Darmstadt, Germany) pre-coated with $1 \%$ normal melting point agarose. After gel solidification at $4^{\circ} \mathrm{C}$, slides were placed in a Coplin jar and immersed in ice-cold lysis solution (2.5 M NaCl, 100 mM Na${ }_{2}$ EDTA, $10 \mathrm{mM}$ Tris-base, $10 \mathrm{M} \mathrm{NaOH}, \mathrm{pH}$ 10 , supplemented with $1 \%$ Triton-X 100) for 1.5 hours at $4^{\circ} \mathrm{C}$ (protected from light), to lyse the cells and separate DNA from histones. For DNA unwinding, all slides were immersed in freshly prepared electrophoresis buffer (200 mM Na 2 EDTA, $0.3 \mathrm{M} \mathrm{NaOH} \mathrm{pH}>13$ ) in the electrophoresis unit for 40 minutes at $4^{\circ} \mathrm{C}$, followed by electrophoresis for 20 minutes at $30 \mathrm{~V}$ and $300 \mathrm{~mA}$. Then, the gels were washed with $\mathrm{H}_{2} \mathrm{O}$ and fixed with ethanol $70 \%$ and $96 \%$ for 15 minutes each, at room temperature. After air-drying the slides overnight, DNA was stained with a $0.07 \% \mathrm{SYBR}^{\circledR}$ Gold solution. The slides were coded, and one scorer performed the comet analysis using a fluorescence microscope (Nikon Eclipse E400 microscope (Amsterdam, Netherlands) attached to an epifluorescence illuminator Nikon C-SHG1) with a 400× magnification and the image analysis software Comet Assay IV (Perceptive Instruments, Bury St Edmunds, Suffolk, UK). The percentage of DNA in the comet tail (percentage tail intensity) and the olive tail of $400 \mu \mathrm{L}$ of an ice-cold methanol/acetic acid pre-fixing solution (3:5 v/v) under gentle agitation. Samples were centrifuged again, and resuspended in $5 \mathrm{~mL}$ of ice-cold fixing solution (methanol/acetic acid, $5: 1 \mathrm{v} / \mathrm{v}$ ) and then centrifuged (100 g, 10 minutes). The supernatant was decanted, the cell pellets were resuspended in the residual supernatant and dropped on to clean glass slides and air-dried. The slides were stained with $3 \%$ Giemsa and analyzed using a light microscope (Nikon E400 Eclipse) under a high magnification (400-1000x). For this test, two independent experiments were performed, each in duplicate. For scoring, MN frequencies were analyzed in at least 2000 binucleate cells per concentration and in the NC, equally divided among the replicates. The criteria for $\mathrm{MN}$ and binucleate cells scoring were in accordance with the principles described by Fenech (Fenech, 2007). Only the concentrations whose cytotoxicity was below $55 \% \pm 5 \%$ were scored for MN. The cytotoxicity was measured in accordance with the OECD TG 487 (OECD, 2016), by using the cytokinesis-block proliferation index (CBPI), which indicates the average number of cell cycles per cell during the period of exposure to cytoB, and may be used to calculate cell proliferation, as follows:

$$
\begin{aligned}
\% \text { Cytostasis } & =100-100\left[\left(\mathrm{CBPI}_{\mathrm{T}}-1\right) \div ;\left(\mathrm{CBPI}_{\mathrm{C}}-1\right)\right], \mathrm{T}=\text { Test and } \\
\mathrm{C} & =\text { Control }
\end{aligned}
$$

Where:

$$
\mathrm{CBPI}=\frac{(\text { no.mononucleate cells })+(2 \times \text { no.binucleate cells })+(3 \times \text { no.multinucleate cells })}{(\text { Total number of cells })}
$$

moment (OTM) were used as a measure of the amount of DNA damage. At least 100 cells were scored (50 for each replicate gel) and three independent experiments were performed, each in triplicate.

\subsection{Assessment of the chromosomal damage}

The MN assay was performed to evaluate the potential chromosome damage induced by the HG, ODEX and ADH in TK6 cells, according to the OECD test guideline (TG) 487 (OECD, 2016), in the presence of cytoB, an actin polymerization inhibitor. The OECD TG 487 proposed an extended exposure treatment of 1.5-2.0 normal cell cycles. As a result, the doubling time of the TK6 cells was approximately 15 hours, the exposure period used in this work was 24 hours. To carry out the experiment, $1.7 \times 10^{5}$ cells $/ \mathrm{mL}$ were seeded in 12 -well plates and then treated for 24 hours with different concentrations of $\mathrm{HG}_{\text {dil }}$, ODEX and $\mathrm{ADH}$, with $0.04 \mu \mathrm{g} / \mathrm{mL} \mathrm{MMC} \mathrm{(PC)} \mathrm{and} \mathrm{culture}$ medium (NC). At the end of the exposure period, cells were centrifuged (100 g, 7 minutes), resuspended in fresh culture medium and transferred on to a new 12-well plate. The culture medium was then supplemented with cytoB at a final concentration of $4 \mu \mathrm{g} / \mathrm{mL}$. After 30 hours (recovery time), cells were transferred into $15 \mathrm{~mL}$ conical tubes, centrifuged (100 g, 7 minutes) and the supernatant discarded by inverting the tube. The residual supernatant was resuspended by gentle agitation of tubes. Then, cells were incubated in $5 \mathrm{~mL}$ of a hypotonic $0.075 \mathrm{M} \mathrm{KCl}$ solution for 4 minutes followed by the addition
For its determination at least 500 cells per slide were counted.

\subsection{Assessment of mutagenicity}

The mutagenic potential of the HG was assessed by the Ames test, using the Ames MPF ${ }^{\mathrm{TM}}$ Penta I kit (Xenometrix AG, Allschwil, Switzerland) according to the manufacturer's instructions and meeting the requirements of the OECD TG 471 (OECD, 1997). Histidinedependent auxotrophic mutants of Salmonella typhimurium (strains TA98, TA100, TA1535 and TA1537) and tryptophan-dependent auxotrophic mutants of Escherichia coli (strains WP2 uvrA and WP2 [pKM101]) were exposed to the $\mathrm{HG}_{\mathrm{dil}}$ in the absence and presence of metabolic activation (Aroclor 1254-induced rat liver S9 fraction). Briefly, the mutant strains were grown overnight (the two E. coll strains were grown separately overnight and then mixed-E. coli Combo mix) and were exposed to different concentrations of the $\mathrm{HG}_{\text {dil }}$, as well as to a positive and a negative control (PBS), all in triplicate, for 90 minutes (E. coli Combo mix + S9 mix: 20 minutes), at $37^{\circ} \mathrm{C}$, under agitation in liquid minimal histidine (Salmonella strains) or tryptophan (E. coli Combo mix) exposure media. After exposure, the cultures were diluted in $\mathrm{pH}$ indicator medium lacking histidine or tryptophan, transferred on to 384 -well plates and incubated at $37^{\circ} \mathrm{C}$ for 48 hours. The bromocresol purple in the indicator medium turns yellow as the $\mathrm{pH}$ drops because of the catabolic activity of revertant bacteria that grow in the absence of the required amino acid. The 
number of positive (yellow) wells of 48 wells per replicate and concentration were counted and compared with the number of spontaneous revertants obtained in the NC. Specific PCs were used to validate the assay. The PCs used in the absence of metabolic activation (S9 mix) were as follows: $2 \mu \mathrm{g} / \mathrm{mL}$ 2-nitrofluorene for the TA98 strain; 0.1 and $2 \mu \mathrm{g} / \mathrm{mL}$ 4-nitroquinoline- $\mathrm{N}$-oxide for the TA100 strain and $\mathrm{E}$. coli Combo mix, respectively; $100 \mu \mathrm{g} / \mathrm{mL} \mathrm{N}^{4}$-aminocytidine for the TA1535 strain; and $15 \mu \mathrm{g} / \mathrm{mL}$ 9-aminoacridine for the TA1537 strain. The PCs used in the presence of the S9 mix were 1 and $50 \mu \mathrm{g} / \mathrm{mL}$ 2-aminoanthracene for the TA98 strain and E. coli Combo mix, respectively, and $2.5 \mu \mathrm{g} / \mathrm{mL}$ 2-aminoanthracene for the TA100, TA1535 and TA1537 strains. Evaluation and interpretation of the results were performed according to the manufacturers' recommended criteria. The baseline value corresponds to the mean \pm SD of the NC. If the obtained value was less than 1.0, it was set to 1 . The fold increase over the baseline, which is the ratio of the mean number of positive wells divided by the baseline, was determined for each concentration. A test compound showing a clear concentration-response and/or yields a multiple fold increase greater than 2.0, is classified as a mutagen.

\section{9 | Statistical analysis}

Experimental data are presented as mean \pm SD. Data were analyzed using the Prism ${ }^{\circledR}$ version 6.1 software (GraphPad Software Inc., La Jolla, CA, USA). Statistical analyses of the cytotoxicity and comet assay data were performed by ANOVA followed by the multiple comparison Dunnett post-hoc test. The cytotoxicity concentrationresponse curves were obtained using the method of least squares and the comparison between the curves and log half-maximal inhibitory concentration $\left(\mathrm{IC}_{50}\right)$ values were performed using extra sum-of-squares $\mathrm{F}$-test. For the $\mathrm{MN}$ assay data, a chi-squared test was performed to test differences of the $\mathrm{MN}$ frequency between exposed and control cells. Significance was accepted at $P<0.05$.

\section{3 | RESULTS}

\subsection{Effects on cellular viability}

The cytotoxicity of the HG was evaluated based on the impact of the $\mathrm{HG}_{\mathrm{dil}}$ and its constituents on cellular viability as assessed by the MTT reduction assay in TK6 cells following 24 hours of exposure to the compounds. As shown in Figure 2, exposure to the $\mathrm{HG}_{\text {dil }}$ markedly decreased cell viability in a concentration-dependent manner down to $41.49 \% \pm 2.80 \%$ of control. Regarding the effects of the isolated components of the HG upon cell viability, it was observed that $\mathrm{ADH}$ did not induce any significant cytotoxicity at the tested concentrations, while ODEX significantly decreased the viability of the cells, also in a concentration-dependent manner, suggesting that the cytotoxicity of $\mathrm{HG}_{\text {dil }}$ is due to the ODEX. Analysis of the concentration-responses curves for the $\mathrm{HG}_{\mathrm{dil}}$ and ODEX (Supporting information Figure S1) revealed half-maximal inhibitory concentration $\left(\mathrm{IC}_{50}\right)$ values of 2.810 (Cl: 2.451-3.316) and $1.147(\mathrm{Cl}: 1.022-1.291) \mathrm{mg} / \mathrm{mL}$, respectively.

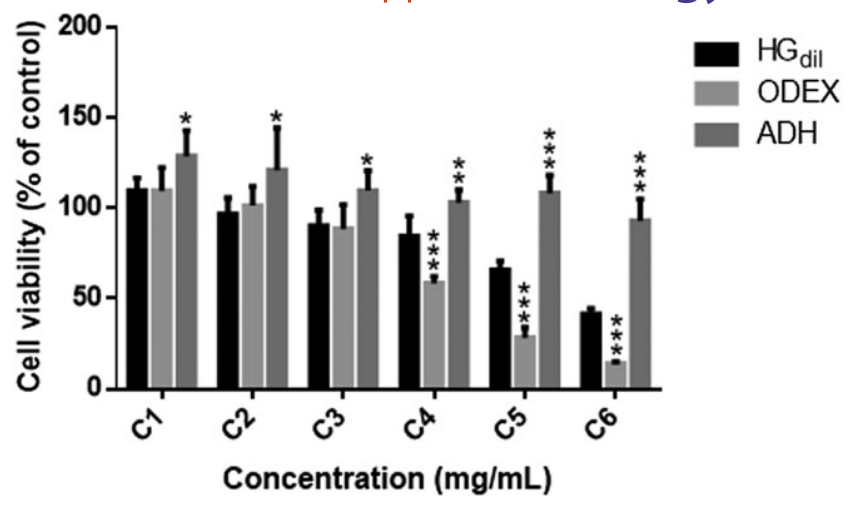

FIGURE 2 Effect of the different concentrations of the $\mathrm{HG}_{\text {dil }}$ and its isolated components-ODEX and ADH-on TK6 cell viability as assessed by the MTT reduction assay. Cells were exposed to different concentrations (C1-C6) of the test agents for $24 \mathrm{~h}$. Results were calculated as percentage of the negative control and data are presented as mean \pm SD ( $n=3$ replicates per group) of two independent experiments. Data were analyzed by one-way ANOVA followed by Dunnett's post hoc test: ${ }^{*} P<0.05,{ }^{* *} P<0.01$ and ${ }^{* * *} P<0.001$ vs. $\mathrm{HG}_{\text {dil }}$. $A D H$, adipic acid dihydrazide; $\mathrm{HG}_{\text {dil }}$, diluted hydrogel; ODEX, oxidized dextrin

\subsection{Effects on DNA level}

Based on the above cytotoxicity data, three non-cytotoxic concentrations of the $\mathrm{HG}_{\text {dil }}$ and of its isolated components (ODEX and ADH) were selected (C1-C3) to investigate their potential DNA damaging effect, by the comet assay, in human lymphoblastoid TK6 cells after 24 hours of exposure. The obtained results are represented in Table 2. The TK6 cell line showed low levels of baseline DNA damage

TABLE 2 Comet assay analysis of DNA damage in TK6 cells exposed for $24 \mathrm{~h}$ to different concentrations of the $\mathrm{HG}_{\text {dil }}$ and its isolated components, ODEX and ADH

\begin{tabular}{|c|c|c|c|}
\hline & & Tail intensity (\%) & Olive tail moment \\
\hline NC & & $7.02 \pm 1.38$ & $0.92 \pm 0.26$ \\
\hline \multicolumn{4}{|l|}{$H G_{\text {dil }}$} \\
\hline & $\mathrm{C} 1$ & $7.13 \pm 0.87$ & $0.93 \pm 0.32$ \\
\hline & $\mathrm{C} 2$ & $7.60 \pm 1.47$ & $0.98 \pm 0.41$ \\
\hline & C3 & $7.84 \pm 1.57$ & $1.08 \pm 0.36$ \\
\hline \multicolumn{4}{|c|}{ ODEX } \\
\hline & $\mathrm{C} 1$ & $7.15 \pm 1.54$ & $0.99 \pm 0.40$ \\
\hline & $\mathrm{C} 2$ & $7.60 \pm 1.49$ & $1.11 \pm 0.41$ \\
\hline & C3 & $8.58 \pm 1.41$ & $1.30 \pm 0.39$ \\
\hline \multicolumn{4}{|l|}{$\mathrm{ADH}$} \\
\hline & $\mathrm{C} 1$ & $6.93 \pm 1.06$ & $0.88 \pm 0.32$ \\
\hline & $\mathrm{C} 2$ & $7.17 \pm 1.51$ & $0.89 \pm 0.27$ \\
\hline & C3 & $6.37 \pm 1.48$ & $0.82 \pm 0.33$ \\
\hline MMS & & $73.98 \pm 8.67^{*}$ & $22.92 \pm 6.99^{*}$ \\
\hline
\end{tabular}

ADH, adipic acid dihydrazide; $H_{\text {dil, }}$ diluted dextrin-based hydrogel; $M M S$, methyl methanesulfonate; NC, negative control; ODEX, oxidized dextrin.

MMS (40 $\mu \mathrm{g} / \mathrm{mL}, 1 \mathrm{~h}$ ) was used as positive control. Results are presented as mean $\pm S D$ ( $n=3$ replicates per group) of three independent experiments. Data were analyzed by one-way ANOVA followed by Dunnett's post hoc test:

${ }^{*} P<0.001$ vs. NC. 
as demonstrated by its percentage tail intensity (7.02 \pm 1.38$)$ and OTM $(0.92 \pm 0.26)$ values. As depicted in Figure 3 , cells exposed to different concentrations of the $\mathrm{HG}_{\text {dil }}$, ODEX and $\mathrm{ADH}$ displayed a predominant round-shaped nucleus similar to the control cells (NC) indicating that the HG and its components did not cause significant DNA damage in human lymphoblastoid cells. As expected cells exposed to MMS (PC) exhibited a pronounced comet tail indicative of DNA damage accompanied by a significant increase in both percentage tail intensity $(73.98 \pm 8.67)$ and OTM (22.92 \pm 6.99$)$ compared with control cells.

\section{3 | Effects on chromosomal level}

The $\mathrm{MN}$ scoring was only performed in concentrations of $\mathrm{HG}_{\mathrm{dil}}$, ODEX and $\mathrm{ADH}$ inducing cytotoxicity levels below $55 \% \pm 5 \%$, as cell death can confound the interpretation of the CBMN assay data. The results relative to $\mathrm{MN}$ frequency (percentage $\mathrm{MN}$ ) in binucleate cells exposed to HG, ODEX and ADH and its respective cytotoxicity are presented in Figure 4. In agreement with the MTT assay data, the $\mathrm{HG}_{\text {dil }}$ and ODEX induced a concentration-dependent increase in cytotoxicity, greater in ODEX-exposed cells, while ADH did not cause cytotoxicity. TK6 cells treated with the highest HG concentration $(3.494 \mathrm{mg} / \mathrm{mL})$ exhibited high levels of cytotoxicity $(89.99 \% \pm 2.26 \%$ of control), and accordingly were not scored for MN frequency. Regarding ODEX, cells incubated with the concentration $\mathrm{C} 5(1.770 \mathrm{mg} / \mathrm{mL})$ displayed a cytotoxicity of $89.28 \% \pm 1.27 \%$ of control, so that, only four concentrations of ODEX were scored for MN. As ADH was not cytotoxic, all the concentrations tested were used for MN scoring. After 24 hours of TK6 cell incubation with the tested concentrations of $\mathrm{HG}_{\text {dil }}$, ODEX and $\mathrm{ADH}$ no significant $\mathrm{MN}$ induction was observed, while $\mathrm{MMC}$ (with a cytotoxicity of $37.46 \% \pm 1.37 \%$ ) significantly increased the number of binucleate cells with $\mathrm{MN}(P<0.001)$ compared to control cells. These results indicate that HG does not induce chromosome damage on TK6 cells under our experimental conditions.

\section{4 | Mutagenic effects}

Data obtained in the Ames test for mutagenicity, in the presence and in the absence of human S9 fraction are presented in Tables 3 and 4, respectively. The results showed that $\mathrm{HG}_{\mathrm{dil}}$ did not induce a twofold increase in the number of positive wells in any of the strains used compared to the NC at any of the concentrations tested, in either the presence or absence of S9 metabolic activation. In addition, a clear dose-dependent increase was not observed in the number of positive wells. On the other hand, all the mutagenic PCs tested produced more than a threefold increase in the number of revertant colonies compared to the NC. Taken together, the above-described results indicated that HG is not mutagenic, at least up to $3.5 \mathrm{mg} / \mathrm{mL}$.

\section{4 | DISCUSSION}

In the present work, a combination of different genotoxicity assays was used to assess the genotoxic potential of the $\mathrm{HG}$ and its isolated components (ODEX and ADH), which were tested in a mammalian cell line but also in prokaryotic models.

The mammalian cell line used was TK6 human lymphoblastoid cells. These cells have a wild-type p53 gene, are karyotypically stable, display DNA repair capacity and stable spontaneous mutation frequencies (Islaih et al., 2005; Lorge et al., 2016; Pfuhler et al., 2011; Zhang et al., 1995). According to the 5th International Workshop on
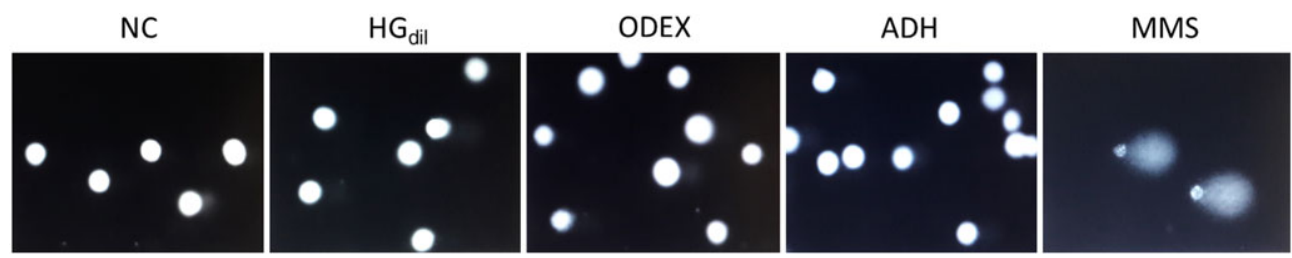

FIGURE 3 . Representative images (400x magnification) of the comet assay in TK6 cells after $24 \mathrm{~h}$ of exposure to NC and to the highest tested concentration (C3) of the $\mathrm{HG}_{\text {dil }}(0.491 \mathrm{mg} / \mathrm{mL})$, ODEX $(0.466 \mathrm{mg} / \mathrm{mL})$ and $\mathrm{ADH}(0.034 \mathrm{mg} / \mathrm{mL})$ used. MMS $(40 \mu \mathrm{g} / \mathrm{mL}, 1 \mathrm{~h})$ was used as positive control. $\mathrm{ADH}$, adipic acid dihydrazide; $\mathrm{HG}_{\text {dil }}$, diluted hydrogel; $\mathrm{MMS}$, methyl methanesulfonate; NC, negative control; ODEX, oxidized dextrin [Colour figure can be viewed at wileyonlinelibrary.com]

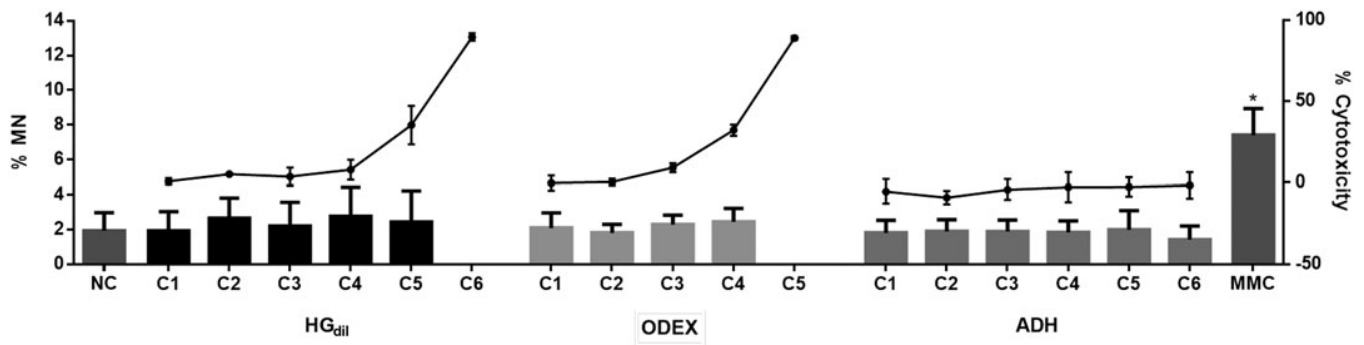

FIGURE 4 Cytokinesis-block MN assay in TK6 cells exposed to different concentrations of the HG dil $_{\text {and }}$ its isolated components-ODEX and $\mathrm{ADH}-$ for $24 \mathrm{~h}$. MMC $(0.04 \mu \mathrm{g} / \mathrm{mL})$ was used as the positive control. Columns: \% MN in binucleate cells; lines: \% cytotoxicity. Results are presented as mean \pm SD ( $n=2$ replicates per group) of two independent experiments. Data were analyzed by chi-squared test: ${ }^{*} P<0.001$ vs. NC. $\mathrm{ADH}$, adipic acid dihydrazide; $\mathrm{HG}_{\mathrm{dil}}$, diluted hydrogel; $\mathrm{MMC}$, mitomycin $\mathrm{C}$; \% $\mathrm{MN}$, percentage of micronucleus; NC, negative control; ODEX, oxidized dextrin 
TABLE 3 Mutagenic potential of the different concentrations of the diluted hydrogel assessed by the Ames test using different strains of $S$. typhimurium (TA98, TA100, TA1535 and TA1537) and a combination of two E. coli strains (E. coli Combo mix), in the absence of metabolic activation (S9 mix)

\begin{tabular}{|c|c|c|c|c|c|c|c|c|c|c|}
\hline & \multicolumn{2}{|l|}{ TA98 } & \multicolumn{2}{|l|}{ TA100 } & \multicolumn{2}{|l|}{ TA1535 } & \multicolumn{2}{|l|}{ TA1537 } & \multicolumn{2}{|c|}{ E. coli Combo mix } \\
\hline & $\begin{array}{l}\text { Positive } \\
\text { wells }\end{array}$ & $\begin{array}{l}\text { Fold } \\
\text { increase }\end{array}$ & $\begin{array}{l}\text { Positive } \\
\text { wells }\end{array}$ & $\begin{array}{l}\text { Fold } \\
\text { increase }\end{array}$ & $\begin{array}{l}\text { Positive } \\
\text { wells }\end{array}$ & $\begin{array}{l}\text { Fold } \\
\text { increase }\end{array}$ & $\begin{array}{l}\text { Positive } \\
\text { wells }\end{array}$ & $\begin{array}{l}\text { Fold } \\
\text { increase }\end{array}$ & $\begin{array}{l}\text { Positive } \\
\text { wells }\end{array}$ & $\begin{array}{l}\text { Fold } \\
\text { increase }\end{array}$ \\
\hline NC & $7.00 \pm 4.36$ & & $10.33 \pm 2.89$ & & $1.33 \pm 0.58$ & & $9.00 \pm 1.73$ & & $8.67 \pm 2.52$ & \\
\hline C1 & $12.33 \pm 3.21$ & 1.09 & $9.33 \pm 2.08$ & 0.71 & $1.67 \pm 1.15$ & 0.87 & $8.00 \pm 3.61$ & 0.75 & $4.33 \pm 0.58$ & 0.39 \\
\hline C2 & $10.33 \pm 1.53$ & 0.91 & $12.76 \pm 3.51$ & 0.96 & $3.00 \pm 1.00$ & 1.57 & $9.67 \pm 2.31$ & 0.90 & $6.67 \pm 2.31$ & 0.60 \\
\hline C3 & $10.33 \pm 0.58$ & 0.91 & $13.00 \pm 4.00$ & 0.98 & $0.67 \pm 0.58$ & 0.35 & $11.67 \pm 3.06$ & 1.09 & $4.00 \pm 2.65$ & 0.36 \\
\hline C5 & $11.00 \pm 2.00$ & 0.97 & $15.33 \pm 4.16$ & 1.16 & $3.00 \pm 0.00$ & 1.57 & $7.00 \pm 2.65$ & 0.65 & $5.00 \pm 1.00$ & 0.45 \\
\hline C6 & $11.00 \pm 2.65$ & 0.97 & $16.67 \pm 4.62$ & 1.26 & $1.67 \pm 2.08$ & 0.87 & $5.67 \pm 1.15$ & 0.53 & $3.33 \pm 2.08$ & 0.30 \\
\hline PC & $48.00 \pm 0.00$ & $4.23^{*}$ & $46.67 \pm 0.58$ & $3.53^{*}$ & $48.00 \pm 0.00$ & $25.12^{*}$ & $48.00 \pm 0.00$ & $4.47^{*}$ & $41.67 \pm 2.08$ & 3.73 \\
\hline
\end{tabular}

NC, negative controls; PC, positive controls.

Results are presented as mean \pm SD. The test compound with a clear concentration-response and/or yields multiple fold increase greater than 2.0 , was classified as a mutagen and was designated with *.

PC were as follows: $2 \mu \mathrm{g} / \mathrm{mL}$ 2-nitrofluorene for the TA98; 0.1 and $2 \mu \mathrm{g} / \mathrm{mL}$ 4-nitroquinoline- $\mathrm{N}$-oxide for the TA100 and E. coli Combo mix, respectively; $100 \mu \mathrm{g} / \mathrm{mL} \mathrm{N}^{4}$-aminocytidine for the TA1535; and $15 \mu \mathrm{g} / \mathrm{mL}$ 9-aminoacridine for the TA1537.

TABLE 4 Mutagenic potential of the different concentrations of the diluted hydrogel assessed by the Ames test using different strains of Salmonella typhimurium (TA 98, TA 100, TA 1535 and TA 1537) and a combination of two Escherichia coli strains (E. coli Combo mix), in the presence of metabolic activation (S9 mix)

\begin{tabular}{|c|c|c|c|c|c|c|c|c|c|c|}
\hline & \multicolumn{2}{|l|}{ TA98 } & \multicolumn{2}{|l|}{ TA100 } & \multicolumn{2}{|l|}{ TA1535 } & \multicolumn{2}{|l|}{ TA1537 } & \multicolumn{2}{|c|}{ E. coli Combo mix } \\
\hline & $\begin{array}{l}\text { Positive } \\
\text { wells }\end{array}$ & $\begin{array}{l}\text { Fold } \\
\text { increase }\end{array}$ & $\begin{array}{l}\text { Positive } \\
\text { wells }\end{array}$ & $\begin{array}{l}\text { Fold } \\
\text { increase }\end{array}$ & $\begin{array}{l}\text { Positive } \\
\text { wells }\end{array}$ & $\begin{array}{l}\text { Fold } \\
\text { increase }\end{array}$ & $\begin{array}{l}\text { Positive } \\
\text { wells }\end{array}$ & $\begin{array}{l}\text { Fold } \\
\text { increase }\end{array}$ & $\begin{array}{l}\text { Positive } \\
\text { wells }\end{array}$ & $\begin{array}{l}\text { Fold } \\
\text { increase }\end{array}$ \\
\hline NC & $3.67 \pm 2.08$ & & $6.33 \pm 2.52$ & & $1.33 \pm 0.58$ & & $3.33 \pm 1.53$ & & $4.00 \pm 1.73$ & \\
\hline C1 & $1.33 \pm 1.53$ & 0.23 & $7.00 \pm 2.00$ & 0.79 & $0.67 \pm 1.15$ & 0.35 & $3.00 \pm 1.73$ & 0.62 & $6.00 \pm 1.73$ & 1.05 \\
\hline C2 & $2.00 \pm 1.00$ & 0.35 & $7.33 \pm 1.53$ & 0.83 & $0.33 \pm 0.58$ & 0.17 & $1.67 \pm 0.58$ & 0.34 & $2.33 \pm 1.53$ & 0.41 \\
\hline C3 & $1.67 \pm 0.58$ & 0.29 & $8.67 \pm 2.52$ & 0.98 & $0.67 \pm 0.58$ & 0.35 & $4.00 \pm 2.00$ & 0.82 & $3.67 \pm 2.89$ & 0.64 \\
\hline C5 & $2.33 \pm 2.52$ & 0.41 & $5.67 \pm 1.53$ & 0.64 & $0.67 \pm 0.58$ & 0.35 & $2.33 \pm 2.08$ & 0.48 & $4.67 \pm 1.15$ & 0.81 \\
\hline C6 & $2.00 \pm 1.00$ & 0.35 & $10.00 \pm 0.00$ & 1.13 & $1.67 \pm 1.15$ & 0.87 & $3.00 \pm 1.73$ & 0.62 & $3.33 \pm 1.53$ & 0.58 \\
\hline PC & $48 \pm 0.00$ & $8.35^{*}$ & $47.67 \pm 0.58$ & $5.39^{*}$ & $27.67 \pm 7.57$ & $14.48^{*}$ & $48.00 \pm 0.00$ & $9.87^{*}$ & $32.00 \pm 2.00$ & $5.58^{*}$ \\
\hline
\end{tabular}

NC, negative controls; PC, positive controls.

Results are presented as mean \pm SD. According to the manufacturer's criteria, a test compound with a clear concentration-response and/or yields multiple fold increase greater than 2.0, was classified as a mutagen and was designated with *

Positive controls (PCs) were as follows: 1 and $50 \mu \mathrm{g} / \mathrm{mL}$ 2-aminoanthracene for the TA98 strain and E. coli Combo mix, respectively, and 2.5 $\mu \mathrm{g} / \mathrm{mL}$ 2aminoanthracene for the TA100, TA1535 and TA1537 strains.

Genotoxicity Testing guidelines, human p53-competent are preferable to p53-compromised cells for evaluation of the $\mathrm{MN}$ induction for human risk assessment (Pfuhler et al., 2011), because of "false" positive results obtained in the p53-compromised rodent cell lines (e.g., V79, CHL and CHO cells) (Fowler et al., 2012). In this way, due to inherent characteristics, TK6 cell line is already recommended in the OECD TG 487 on in vitro mammalian cell MN test (OECD, 2016), being one of the most used cell models for such assay (Lorge et al., 2016). Another advantage of using TK6 cells is that it is a wellstudied human cell line, ease of culturing and its use eliminates the donor to donor variability observed with primary human lymphocytes (Sobol et al., 2012). Consequently, TK6 cell line may be deemed appropriate for performing in vitro genotoxicity assessment of medical devices for tissue regeneration purposes to be applied in tissues highly vascularized, such as bone.

To avoid misleading positive results in the comet and CBMN assays, the different concentrations of $\mathrm{HG}_{\mathrm{dil}}$, ODEX and $\mathrm{ADH}$ were first evaluated for their cytotoxicity. The results from the MTT reduction and $\mathrm{CBMN}$ (using CBPI method) showed that $\mathrm{HG}_{\text {dil }}$ reduced the viability in TK6 cells, in a concentration-dependent manner. Analysis of the isolated components of HG revealed that while ADH was non-cytotoxic, ODEX induced cytotoxicity in a concentrationdependent manner. It is important to note that ADH is a minor component of the $\mathrm{HG}(\sim 5 \% \mathrm{w} / \mathrm{w})$, thus lower concentrations were tested. Silva et al. evaluated and compared the cytotoxicity of ADH and glutaraldehyde (Silva et al., 2014). The latter is a widely used crosslinker, 
often reported to be cytotoxic (Huang-Lee, Cheung, \& Nimni, 1990; McPherson, Sawamura, \& Armstrong, 1986), but still used for reticulation of biomedical products (Fürst \& Banerjee, 2005). Silva et al. showed that glutaraldehyde caused a much higher cytotoxicity than $\mathrm{ADH}$ in fibroblast $3 \mathrm{~T} 3$ cells, while dihydrazide-induced cell death occurred only at concentrations 300 times higher than those of glutaraldehyde (Silva et al., 2014), which supports its use as a preferable crosslinker for biomedical applications. Our results strongly suggest that the cytotoxic effect of the $\mathrm{HG}_{\text {dil }}$ is most likely attributable to the presence of ODEX free aldehydes. The formation of the HG depends on the reaction of aldehydes present in ODEX with free amines provided by $\mathrm{ADH}$, producing hydrazone bonds, and the degradation of HG is caused by the hydrolysis of those hydrazone bonds, yielding again the original free ODEX and ADH components (Molinos et al., 2012). Therefore, the biological reactivity of the HG is likely to the presence of excess aldehyde groups, those not involved in hydrazone bond formation. This phenomenon can also explain the stronger cytotoxic effect of ODEX when used alone compared to the HG, in TK6 cells exposed to higher concentrations of these agents (C4, C5 and C6), i.e., ODEX by itself is more reactive than in the presence of $A D H$ as all its aldehyde groups are free, while during formation of the HG some of the aldehydes react with $A D H$, thus reducing the number of free aldehydes. The toxicity of other types of aldehyde-modified polysaccharides has been already reported for other cell types, such as human and murine fibroblasts (Aziz et al., 2015; Draye et al., 1998; Hyon, Nakajima, Sugai, \& Matsumura, 2014; Rousseau \& Gagnieu, 2002), macrophage cells (THP-1 and RAW 264.7) (Aziz et al., 2015; Sokolsky-Papkov, Domb, \& Golenser, 2006), epidermal keratinocytes, endothelial cells (Draye et al., 1998) and nasopharyngeal epithelial cells (Aziz et al., 2015). For instance, Aziz et al. (2015) assessed the cytotoxicity of the aldehyde-modified dextran (DA; $1.25-30 \mathrm{mg} / \mathrm{mL}$ ) using the xCELLigence system for 98 hours. DA showed a strong, dose-dependent cytotoxic effect at concentrations greater than $2.5 \mathrm{mg} / \mathrm{mL}$ in epithelial and macrophage cells. Macrophage cells at the lowest DA concentration, however, showed a mild inhibitory effect with a $\sim 20 \%$ reduction in cell viability. In fibroblasts, DA displayed a strong decrease of cell viability at conditions greater than $5 \mathrm{mg} / \mathrm{mL}$. After the combination between DA and succinyl chitosan to obtain the dextran-based hydrogel, this showed a strong and immediate cytotoxic effect in epithelial cells, in contrast to the macrophage and fibroblast cells, which exhibited a more moderate response with a $\sim 40 \%$ overall reduction in cell viability (Aziz et al., 2015). The cytotoxic effect of aldehydes is most likely due to their reaction with amino acids of the culture medium and free amines in the cell, causing a negative effect on cellular growth (Hyon et al., 2014; Rousseau \& Gagnieu, 2002). When the excess of aldehyde groups is reduced to a primary alcohol (Rousseau \& Gagnieu, 2002; Sokolsky-Papkov et al., 2006) or the degree of oxidation of the backbone is reduced (Chan, Brooks, Moratti, Hanton, \& Cabral, 2015), the biocompatibility is highly improved. Although the aldehyde-modified polysaccharide derivatives showed some degree of cytotoxicity in vitro, several studies have shown biocompatibility, safety and good performance in vivo in diverse biomedical applications, such as hydrogels for the prevention of postoperative adhesions (Athanasiadis et al., 2008; Ito et al., 2007; Lauder, Strickland, \& Maddern, 2012), surgical hemostatics (Rajiv et al., 2013), bioadhesives and sealants (Artzi, Shazly, Baker, Bon, \& Edelman, 2009; Hoffmann et al., 2009). In fact, our group has already shown that the HG presents excellent in vivo biocompatibility in a subcutaneous implantation assay (Silva et al., 2016). This finding may be explained by the slow degradation of the HG in vivo and by dilution/excretion of the solubilized products, which most likely never will reach the concentrations proved cytotoxic in the present work.

Despite extensive research on cytotoxicity (effects on cell proliferation/viability) of aldehyde-modified polysaccharides and $A D H$, genotoxicity studies are still scarce, in particular, on $A D H$ reticulated polyaldehyde-based hydrogels (Bouhadir, Hausman, \& Mooney, 1999; Hu et al., 2017; Maia et al., 2009; Schramm et al., 2012; Su, Chen, \& Lin, 2010). Genotoxicity is an important endpoint of the safety assessment of regulated products, but no single test is available to detect all types of genotoxicity. Therefore, a battery of standard genotoxicity assays is recommended by ISO 10993-3 (2014) for the screening of potential genotoxicants. In this study, a detailed genotoxicity assessment of a dextrin-based hydrogel and its isolated components to be used in medical devices for bone regeneration was performed, using the CBMN, comet and the Ames assays. Among these tests, CBMN and Ames are set out in ISO 10993-3 guideline.

The CBMN assay is a sensitive method, which detects chromosomal damage in cells that have undergone cell division during or following exposure to a test agent, through the observation of a $M N$. The MN results from chromosomal loss or fragmentation, where this damaged genetic material lags behind during chromosome segregation and is not included in either of the resulting daughter nuclei (Fenech, 2007). Our data showed that the HG, as well as its individual components, did not induce an increase of MN frequency in binucleate cells, suggesting that this dextrin-based hydrogel does not promote chromosomal mutations.

The comet assay is a versatile, sensitive and rapid method for measuring DNA single- and double-strand breaks at the level of individual cells (Tice et al., 2000). It has been proposed as a valuable addition to the $\mathrm{MN}$ assay due to its independence from cell proliferation and coverage of a wider spectrum of DNA damage (Pfuhler et al., 2011) such as strand breaks originated from direct interactions of a test agent with the DNA molecule, alkali labile sites or transient DNA strand breaks resulting from DNA excision repair mechanisms. This damage on DNA either can be repaired, with no consequences for the cell, or may be fixed into a mutation resulting in a permanent viable change or even may be lethal to the cell. It may also lead to chromosomal damage, which is also associated with many human diseases, including cancer (Fenech, 2007). In this test, the length and fluorescence intensity of the comet tail is directly proportional to the amount of DNA damage (Tice et al., 2000). In our study, the basal DNA damage observed in TK6 cells were comparable to that reported by others (Sharma et al., 2017; Sotiriou et al., 2014). The results of the percentage tail intensity and OTM for cells exposed to $\mathrm{HG}_{\text {dil }}$, ODEX and $\mathrm{ADH}$ were similar to the control, indicating that none of them promoted DNA damage at the concentrations tested. Genotoxic potential, by using comet assay method, of self-assembling dextrin nanogels (Dextrin-MVA-SC16: MVA [vinyl methacrylate]; SC16 [alkyl chain]) has been reported, showing an absence of DNA damage in 3T3 fibroblasts and murine bone marrow-derived macrophages in a range of concentrations between 0.1 and $1 \mathrm{mg} / \mathrm{mL}$ of nanogel (Carvalho et al., 2011). 
The Ames test is the most classic test to evaluate the mutagenic potential of chemicals. It is commonly employed as an initial screening for genotoxic activity and, in particular, for point mutation-inducing activity. Point mutations are the cause of many human genetic diseases and there is substantial evidence that point mutations in oncogenes and tumor suppressor genes of somatic cells are involved in tumor formation in humans (Tubbs \& Nussenzweig, 2017). To test the mutagenic toxicity of metabolized products, the $S 9$ fraction, a rat liver extract, was used in the assays.

Strains with different sensitivities to detect base substitutions and frameshift mutations were used. In our study, the low number of positive wells and the lack of a dose-response, either in the presence or absence of S9 fractions suggest that the HG and its metabolites lack mutagenic activity at the concentrations tested. Negative mutagenicity results have been also reported for an HG composed by succinyl chitosan and aldehyde dextran $(0.5-8 \mathrm{mg} / \mathrm{mL})$ as assessed by the Ames test (Aziz et al., 2015).

In conclusion, in this work, an oxidized dextrin-based hydrogel reticulated with $\mathrm{ADH}$, previously developed by our group, aiming to perform as an injectable carrier of hydroxyapatite granules for bone tissue engineering and as a drug delivery system was characterized for cyto- and genotoxicity. Genotoxicity is an important endpoint in the safety assessment of medical devices but is often undervalued by polymeric biomaterial researchers in the biomedical field. The obtained results demonstrated that $\mathrm{HG}$ is non-genotoxic and non-mutagenic under the experimental conditions tested, confirming the huge potential of this HG for biomedical applications. In vivo studies are being performed to confirm the safety of HG for such applicability. To the best of our acknowledge, this is the first report with a detailed genotoxicity assessment of an aldehyde-modified polysaccharide/ADH hydrogel.

\section{ACKNOWLEDGEMENTS}

Isabel Pereira was supported by the grant SFRH/BD/90066/2012 from Fundação para a Ciência e a Tecnologia (FCT), Portugal. The authors acknowledge the funding from Fundo Europeu de Desenvolvimento Regional (FEDER) and NORTE 2020 through the project no. 003262 titled "iBONE therapies: advanced solutions for bone regeneration," BioTecNorte operation (NORTE-01-0145FEDER-000004) funded by the European Regional Development Fund under the scope of Norte2020-Programa Operacional Regional do Norte, and through the project MAGICOAT (PTDC/CTM-BIO/2170/ 2014) funded by FCT and COMPETE.

\section{CONFLICT OF INTEREST}

The authors have no conflicts of interest to report.

\section{ORCID}

Isabel Pereira (D) http://orcid.org/0000-0002-9769-7208

\section{REFERENCES}

Artzi, N., Shazly, T., Baker, A. B., Bon, A., \& Edelman, E. R. (2009) Aldehyde-amine chemistry enables modulated biosealants with tissue-specific adhesion. Advanced Materials, 21(32-33), 3399-3403. https://doi.org/10.1002/adma.200900340
Athanasiadis, T., Beule, A. G., Robinson, B. H., Robinson, S. R., Shi, Z., \& Wormald, P.-J. (2008). Effects of a novel chitosan gel on mucosal wound healing following endoscopic sinus surgery in a sheep model of chronic rhinosinusitis. The Laryngoscope, 118(6), 1088-1094. https://doi.org/10.1097/MLG.0b013e31816ba576

Aziz, M. A., Cabral, J. D., Brooks, H. J. L., McConnell, M. A., Fitzpatrick, C., Hanton, L. R., \& Moratti, S. C. (2015). In vitro biocompatibility and cellular interactions of a chitosan/dextran-based hydrogel for postsurgical adhesion prevention. Journal of Biomedical Materials Research Part B: Applied Biomaterials, 103(2), 332-341. https://doi.org/10.1002/jbm. b.33206

Bouhadir, K. H., Hausman, D. S., \& Mooney, D. J. (1999). Synthesis of cross-linked poly (aldehyde guluronate) hydrogels. Polymer, 40(12), 3575-3584. https://doi.org/10.1016/S0032-3861(98)00550-3

Carvalho, V., Castanheira, P., Madureira, P., Ferreira, S. A., Costa, C., Teixeira, J. P., ... Gama, M. (2011). Self-assembled dextrin nanogel as protein carrier: Controlled release and biological activity of IL-10. Biotechnology and Bioengineering, 108(8), 1977-1986. https://doi.org/ 10.1002/bit.23125

Chan, M., Brooks, H., Moratti, S., Hanton, L., \& Cabral, J. (2015). Reducing the oxidation level of dextran aldehyde in a chitosan/dextran-based surgical hydrogel increases biocompatibility and decreases antimicrobial efficacy. International Journal of Molecular Sciences, 16(12), 13798-13814. https://doi.org/10.3390/ijms160613798

Das, D., \& Pal, S. (2015). Modified biopolymer-dextrin based crosslinked hydrogels: application in controlled drug delivery. RSC Advances, 5(32), 25014-25050. https://doi.org/10.1039/C4RA16103C

DeBusk, A. O. V., \& Alleman, T. (2006). Method for preparing medical dressings. Retrieved from https://patents.google.com/patent/WO20040024 60A1/en

Draye, J.-P., Delaey, B., Van de Voorde, A., Van Den Bulcke, A., De Reu, B., \& Schacht, E. (1998). In vitro and in vivo biocompatibility of dextran dialdehyde cross-linked gelatin hydrogel films. Biomaterials, 19(18), 1677-1687. https://doi.org/10.1016/S0142-9612(98)00049-0

Drury, J. L., \& Mooney, D. J. (2003). Hydrogels for tissue engineering: Scaffold design variables and applications. Biomaterials, 24(24), 4337-4351. https://doi.org/10.1016/S0142-9612(03)00340-5

Fenech, M. (2007). Cytokinesis-block micronucleus cytome assay. Nature Protocols, 2(5), 1084-1104. https://doi.org/10.1038/nprot.2007.77

Fowler, P., Smith, K., Young, J., Jeffrey, L., Kirkland, D., Pfuhler, S., \& Carmichael, P. (2012). Reduction of misleading ("false") positive results in mammalian cell genotoxicity assays. I. Choice of cell type. Mutation Research/Genetic Toxicology and Environmental Mutagenesis, 742(1-2), 11-25. https://doi.org/10.1016/j.mrgentox.2011.10.014

Fürst, W., \& Banerjee, A. (2005). Release of glutaraldehyde from an albumin-glutaraldehyde tissue adhesive causes significant in vitro and in vivo toxicity. The Annals of Thoracic Surgery, 79(5), 1522-1528. https://doi.org/10.1016/j.athoracsur.2004.11.054

Geckil, H., Xu, F., Zhang, X., Moon, S., \& Demirci, U. (2010). Engineering hydrogels as extracellular matrix mimics. Nanomedicine, 5(3), 469-484. https://doi.org/10.2217/nnm.10.12

Gonçalves, C., Moreira, S. M., Carvalho, V., Silva, D. M., \& Gama, M. (2016). Dextrin. In M. Mishra (Ed.), Encyclopedia of Biomedical Polymers and Polymeric Biomaterials (1st ed.) (pp. 2634-2649). New York: Taylor \& Francis. https://doi.org/10.1081/E-EBPP-120050698

Hoare, T. R., \& Kohane, D. S. (2008). Hydrogels in drug delivery: Progress and challenges. Polymer, 49(8), 1993-2007. https://doi.org/10.1016/j. polymer.2008.01.027

Hoffmann, B., Volkmer, E., Kokott, A., Augat, P., Ohnmacht, M., Sedlmayr, N., ... Ziegler, G. (2009). Characterisation of a new bioadhesive system based on polysaccharides with the potential to be used as bone glue. Journal of Materials Science: Materials in Medicine, 20(10), 2001-2009. https://doi.org/10.1007/s10856-009-3782-5

Hreczuk-Hirst, D., Chicco, D., German, L., \& Duncan, R. (2001). Dextrins as potential carriers for drug targeting: tailored rates of dextrin degradation by introduction of pendant groups. International Journal of 
Pharmaceutics, 230(1-2), 57-66. Retrieved from www.elsevier.com/ locate/ijpharm. https://doi.org/10.1016/S0378-5173(01)00859-6

Hu, M., Yang, K., Sun, Y., Chen, Y., Yang, S., \& Lin, F. (2017). In situ forming oxidised hyaluronic acid/adipic acid dihydrazide hydrogel for prevention of epidural fibrosis after laminectomy. European Cells and Materials, 307-320. https://doi.org/10.22203/eCM.v034a19

Huang-Lee, L. L. H., Cheung, D. T., \& Nimni, M. E. (1990). Biochemical changes and cytotoxicity associated with the degradation of polymeric glutaraldehyde derived crosslinks. Journal of Biomedical Materials Research, 24(9), 1185-1201. https://doi.org/10.1002/jbm.820240905

Hyon, S.-H., Nakajima, N., Sugai, H., \& Matsumura, K. (2014). Low cytotoxic tissue adhesive based on oxidized dextran and epsilon-poly-Ilysine. Journal of Biomedical Materials Research Part A, 102(8), 2511-2520. https://doi.org/10.1002/jbm.a.34923

Islaih, M., Halstead, B. W., Kadura, I. A., Li, B., Reid-Hubbard, J. L., Flick, L., ... Newton, R. K. (2005). Relationships between genomic, cell cycle, and mutagenic responses of TK6 cells exposed to DNA damaging chemicals. Mutation Research/Fundamental and Molecular Mechanisms of Mutagenesis, 578(1-2), 100-116. https://doi.org/10.1016/j. mrfmmm.2005.04.012

ISO 10993-1. (2009). Biological evaluation of medical devices-Part 1: Evaluation and testing within a risk management process. Retrieved from https://www.iso.org/standard/44908.htm

ISO 10993-3. (2014). Biological evaluation of medical devices-Part 3: Tests for genotoxicity, carcinogenicity and reproductive toxicity. Retrieved from https://www.iso.org/standard/55614.html

ISO 10993-5. (2009). Biological evaluation of medical devices-Part 5: Tests for in vitro cytotoxicity. Retrieved from https://www.iso.org/ standard/36406.html

Ito, T., Yeo, Y., Highley, C. B., Bellas, E., Benitez, C. A., \& Kohane, D. S. (2007). The prevention of peritoneal adhesions by in situ cross-linking hydrogels of hyaluronic acid and cellulose derivatives. Biomaterials, 28(6), 975-983. https://doi.org/10.1016/j.biomaterials.2006.10.021

Lauder, C. I. W., Strickland, A., \& Maddern, G. J. (2012). Use of a modified chitosan-dextran gel to prevent peritoneal adhesions in a porcine hemicolectomy model. Journal of Surgical Research, 176(2), 448-454. https://doi.org/10.1016/j.jss.2011.10.029

Lorge, E., Moore, M. M., Clements, J., O'Donovan, M., Fellows, M. D., Honma, M., ... Tanir, J. Y. (2016). Standardized cell sources and recommendations for good cell culture practices in genotoxicity testing. Mutation Research/Genetic Toxicology and Environmental Mutagenesis, 809, 1-15. https://doi.org/10.1016/j.mrgentox.2016.08.001

Maia, J., Ribeiro, M. P., Ventura, C., Carvalho, R. A., Correia, I. J., \& Gil, M. H. (2009). Ocular injectable formulation assessment for oxidized dextran-based hydrogels. Acta Biomaterialia, 5(6), 1948-1955. https://doi.org/10.1016/j.actbio.2009.02.008

McPherson, J. M., Sawamura, S., \& Armstrong, R. (1986). An examination of the biologic response to injectable, glutaraldehyde cross-linked collagen implants. Journal of Biomedical Materials Research, 20(1), 93-107. https://doi.org/10.1002/jbm.820200109

Mesquita, B., Lopes, I., Silva, S., Bessa, M. J., Starykevich, M., Carneiro, J., .. Fraga, S. (2017). Gold nanorods induce early embryonic developmental delay and lethality in zebrafish (Danio rerio). Journal of Toxicology and Environmental Health, Part A, 80(13-15), 672-687. https://doi.org/ 10.1080/15287394.2017.1331597

Molinos, M., Carvalho, V., Silva, D. M., \& Gama, F. M. (2012). Development of a hybrid dextrin hydrogel encapsulating dextrin nanogel as protein delivery system. Biomacromolecules, 13(2), 517-527. https://doi.org/ 10.1021/bm2015834

Moreira, S., Gil Da Costa, R. M., Guardao, L., Gartner, F., Vilanova, M., \& Gama, M. (2010). In vivo biocompatibility and biodegradability of dextrin-based hydrogels. Journal of Bioactive and Compatible Polymers, 25(2), 141-153. https://doi.org/10.1177/0883911509357865

OECD (1997). Test No. 471: Bacterial Reverse Mutation Test. Paris: OECD Publishing. https://doi.org/10.1787/9789264071247-en
OECD (2016). Test No. 487: In Vitro Mammalian Cell Micronucleus Test. Paris: OECD Publishing. https://doi.org/10.1787/9789264264861-en

Peers, E., \& Gokal, R. (1998). Icodextrin provides long dwell peritoneal dialysis and maintenance of intraperitoneal volume. Artificial Organs, 22(1), 8-12. Retrieved from http://www.ncbi.nlm.nih.gov/pubmed/9456219

Pereira, I., Simões, J., Evtyugin, D. V., Rouif, S., Coimbra, M. A., Domingues, M. R. M., \& Gama, M. (2018). Effects of gamma irradiation and periodate oxidation on the structure of dextrin assessed by mass spectrometry. European Polymer Journal, 103, 158-169. https://doi.org/ 10.1016/j.eurpolymj.2018.04.011

Pfuhler, S., Fellows, M., van Benthem, J., Corvi, R., Curren, R., Dearfield, K., ... Speit, G. (2011). In vitro genotoxicity test approaches with better predictivity: Summary of an IWGT workshop. Mutation Research/Genetic Toxicology and Environmental Mutagenesis, 723(2), 101-107. https://doi.org/10.1016/j.mrgentox.2011.03.013

Rajiv, S., Harding, M., Bassiouni, A., Jardeleza, C., Drilling, A., James, C., .. Wormald, P.-J. (2013). The efficacy and safety of chitosan dextran gel in a burr hole neurosurgical sheep model. Acta Neurochirurgica, 155(7), 1361-1366. https://doi.org/10.1007/s00701-013-1767-0

Rousseau, C. F., \& Gagnieu, C. H. (2002). In vitro cytocompatibility of porcine type I atelocollagen crosslinked by oxidized glycogen. Biomaterials, 23(6), 1503-1510. https://doi.org/10.1016/S0142-9612(01)00276-9

Schramm, C., Spitzer, M. S., Henke-Fahle, S., Steinmetz, G., Januschowski, K., Heiduschka, P., ... Szurman, P. (2012). The cross-linked biopolymer hyaluronic acid as an artificial vitreous substitute. Investigative Opthalmology \& Visual Science, 53(2), 613. https://doi.org/10.1167/ iovs.11-7322

Sharma, A., Bányiová, K., Babica, P., El Yamani, N., Collins, A. R., \& Čupr, P. (2017). Different DNA damage response of cis and trans isomers of commonly used UV filter after the exposure on adult human liver stem cells and human lymphoblastoid cells. Science of the Total Environment, 593-594, 18-26. https://doi.org/10.1016/j.scitotenv.2017.03.043

Silva, D. M., Caseiro, A. R., Amorim, I., Pereira, I., Faria, F., Pereira, T., .. Maurício, A. C. (2016). Inflammatory response to dextrin-based hydrogel associated with human mesenchymal stem cells, urinary bladder matrix and Bonelike ${ }^{\circledR}$ granules in rat subcutaneous implants. Biomedical Materials, 11(6), 065004. https://doi.org/10.1088/1748-6041/11/ 6/065004

Silva, D. M., Nunes, C., Pereira, I., Moreira, A. S. P., Domingues, M. R. M., Coimbra, M. A., \& Gama, F. M. (2014). Structural analysis of dextrins and characterization of dextrin-based biomedical hydrogels. Carbohydrate Polymers, 114, 458-466. https://doi.org/10.1016/j.carbpol. 2014.08.009

Sobol, Z., Homiski, M. L., Dickinson, D. A., Spellman, R. A., Li, D., Scott, A. ... Schuler, M. (2012). Development and validation of an in vitro micronucleus assay platform in TK6 cells. Mutation Research/Genetic Toxicology and Environmental Mutagenesis, 746(1), 29-34. https://doi. org/10.1016/j.mrgentox.2012.02.005

Sokolsky-Papkov, M., Domb, A. J., \& Golenser, J. (2006). Impact of aldehyde content on amphotericin B-dextran imine conjugate toxicity Biomacromolecules, 7(5), 1529-1535. https://doi.org/10.1021/ bm050747n

Sotiriou, G. A., Watson, C., Murdaugh, K. M., Darrah, T. H., Pyrgiotakis, G., Elder, A., ... Demokritou, P. (2014). Engineering safer-by-design silica-coated $\mathrm{ZnO}$ nanorods with reduced DNA damage potential Environmental Science: Nano, 1(2), 144. https://doi.org/10.1039/ c3en00062a-153.

Su, W.-Y., Chen, Y.-C., \& Lin, F.-H. (2010). Injectable oxidized hyaluronic acid/adipic acid dihydrazide hydrogel for nucleus pulposus regeneration. Acta Biomaterialia, 6(8), 3044-3055. https://doi.org/10.1016/j. actbio.2010.02.037

Takatori, Y., Akagi, S., Sugiyama, H., Inoue, J., Kojo, S., Morinaga, H., ... Makino, H. (2011). Icodextrin technique survival rate in peritoneal dialysis patients with diabetic nephropathy by improving body fluid management: a randomized controlled trial. Clinical Journal of the American Society of Nephrology, 6(6), 1337-1344. https://doi.org/10.2215/ CJN.10041110 
Tice, R. R., Agurell, E., Anderson, D., Burlinson, B., Hartmann, A. Kobayashi, H., ... Sasaki, Y. F. (2000). Single cell gel/comet assay: Guidelines for in vitro and in vivo genetic toxicology testing. Environmental and Molecular Mutagenesis, 35(3), 206-221. https://doi.org/ 10.1002/(SICI)1098-2280(2000)35:3<206::AID-EM8>3.0.CO;2-J

Tomasik, P., Wiejak, S., \& Pałasiński, M. (1989). The thermal decomposition of carbohydrates. Part II. The decomposition of starch. In Advances in Carbohydrate Chemistry and Biochemistry ( ed., Vol. 47) (pp. 279-343). https://doi.org/10.1016/S0065-2318(08)60416-3

Treetharnmathurot, B., Dieudonné, L., Ferguson, E. L., Schmaljohann, D., Duncan, R., \& Wiwattanapatapee, R. (2009). Dextrin-trypsin and STHPMA-trypsin conjugates: Enzyme activity, autolysis and thermal stability. International Journal of Pharmaceutics, 373(1-2), 68-76. https:// doi.org/10.1016/j.ijpharm.2009.02.008

Tubbs, A., \& Nussenzweig, A. (2017). Endogenous DNA damage as a source of genomic instability in cancer. Cell, 168(4), 644-656. https:// doi.org/10.1016/j.cell.2017.01.002
Zhang, L.-S., Honma, M., Hayahshi, M., Suzuki, T., Matsuoka, A., \& Sofuni, T. (1995). A comparative study of TK6 human lymphoblastoid and L5178Y mouse lymphoma cell lines in the in vitro micronucleus test. Mutation Research Letters, 347(3-4), 105-115. https://doi.org/ 10.1016/0165-7992(95)00027-5

\section{SUPPORTING INFORMATION}

Additional supporting information may be found online in the Supporting Information section at the end of the article.

How to cite this article: Pereira I, Fraga S, Silva S, Teixeira JP, Gama M. In vitro genotoxicity assessment of an oxidized dextrin-based hydrogel for biomedical applications. J Appl Toxicol. 2019;39:639-649. https://doi.org/10.1002/jat.3754 